\title{
RESEARCH Note \\ Comparative anatomy of the caudal skeleton of lantern fishes of the genus Triphoturus Fraser-Brunner, 1949 (Teleostei: Myctophidae)
}

\author{
Anatomía comparada del complejo caudal de los peces linterna del género \\ Triphoturus Fraser-Brunner, 1949 (Teleostei: Myctophidae)

\section{Uriel Rubio-Rodríguez ${ }^{1}$, Adrián F. González-Acosta ${ }^{1}$ and Héctor Villalobos ${ }^{1}$}

\begin{abstract}
${ }^{1}$ Instituto Politécnico Nacional, Departamento de Pesquerías y Biología Marina, CICIMAR-IPN, Av. Instituto Politécnico Nacional s/n, Col. Playa Palo de Santa Rita, La Paz, BCS, 23096, México. urubio33@gmail.com

Abstract.- The caudal skeleton provides important information for the study of the systematics and ecomorphology of teleostean fish. However, studies based on the analysis of osteological traits are scarce for fishes in the order Myctophiformes. This paper describes the anatomy of the caudal bones of 3 Triphoturus species: T. mexicanus (Gilbert, 1890), T. nigrescens (Brauer, 1904) and T. oculeum (Garman, 1899). A comparative analysis was performed on cleared and stained specimens to identify the differences and similarities of bony elements and the organization of the caudal skeleton among the selected species. Triphoturus mexicanus differs from T. oculeum in the presence of medial neural plates and a foramen in the parhypural, while T. nigrescens differs from their congeners in a higher number of hypurals $(2+4=6)$ and the separation and number of cartilaginous elements. This osteological description of the caudal region allowed updates to the nomenclature of bony and cartilaginous elements in myctophids. Further, this study allows for the recognition of structural differences between T. mexicanus and T. oculeum, as well as the major morphological distinction between T. nigrescens and their sister species.
\end{abstract}

Key words: Caudal fin anatomy, osteology, Mexican lantern fish, Highseas lantern fish, Myctophiformes

\section{INTRODUCTION}

Structural components in the caudal skeleton of teleosts and their variation are useful taxonomic traits for intergeneric and specific delineation (e.g., Fraser 1968, Tyler 1980) as well as in the evaluation of teleostean interrelationships (Gosline 1960, Nybelin 1963, Lauder 1989, Schultze \& Arratia 1989, Fujita 1990, Borden et al. 2013, Doosey \& Wiley 2015). For this reason, most ichthyologists consider these as important sources of information for systematic, functional morphology and adaptive radiation in aquatic environments (Johnson 1975, Lauder 1989, 2000; Moriyama \& Takeda 2013). However, the caudal skeleton of higher euteleosts has been studied in only a few taxa (see McDowall 1999), with studies either addressing only certain species (e.g., Potthoff \& Tellock 1993, Doyle 1998, Bartolino 2005), or referring to representative taxa at the generic or family level (e.g., Keivany \& Nelson 1998, Baldwin \& Johnson 1999, Castro-Leal \& Brito 2007). Hence, the descriptive study of the morphology and evolution of the caudal fin in teleosts is yet to be completed (Dunn 1983, Arratia \& Schultze 1992; Schultze \& Arratia 1989, 2013; Castro-Leal \& Brito 2007, Moriyama \& Takeda 2013, Doosey \& Wiley 2015).
The family Myctophidae comprises fishes inhabiting deep, oceanic zones worldwide. This family is characterized by the presence of cephalic, lateral, and ventral photophores, the arrangement of which is an important trait for taxonomic determination (Wisner 1974). Nevertheless, photophores are commonly dislocated during collection, making the identification of species difficult (Wisner 1974).

For some myctophid genera, there are taxonomic issues not yet solved because of the lack of studies on the biology and the morphology of this family. Therefore, it is important to explore tools that can be used as potential sources of information and criteria for the taxonomic identification of species in this group, such as osteology and comparative morphology (Paxton 1972, Hulley 1986, Moser \& Ahlstrom 1996).

In the family Myctophidae, osteological research has focused on establishing the phylogenetic relationships, using key bony features that are unique to the family and related groups or a general description of the skeleton for each genus (e.g., Paxton 1972, Stiassny 1996). However, a detailed analysis of the distribution, shape, size and insertion point of bony structures is 
important for some genera when the information required for species discrimination is missing. This lack of comparative bony studies has not allowed a clear taxonomic differentiation between the members of the genus Triphoturus (e.g., Paxton 1972, Hulley 1986, Moser \& Ahlstrom 1996).

The anatomical information currently available for Triphoturus is insufficient for establishing the number of species that inhabit the Eastern Pacific Ocean. Therefore, the aim of this study was to perform the comparative analysis of the caudal skeleton in 3 species of this genus, to provide information for the taxonomic discrimination and the establishment of relationships between species in this genus.

\section{MATERIALS AND METHODS}

A total of 58 specimens were analyzed from fish collections deposited in the Centro Interdisciplinario de Ciencias Marinas (CICIMAR-CI) and the Scripps Institution of Oceanography (SIO): 13 specimens of Triphoturus nigrescens (Brauer, 1904) from the California Current, 16 of T. oculeum (Garman, 1899) from Colombia, Ecuador and Peru, and 18 of T. mexicanus (Gilbert, 1890) from the Gulf of California (7 specimens) and the California Current (11 specimens).

All specimens were processed by the clearing and staining method described by Taylor (1967) with amendments by Pothoff (1984). The dissection and identification of caudal elements was based on the bone nomenclature proposed by Gosline (1961), Nybelin (1963), Paxton (1972) and Rojo (1991), whereas the nomenclature of cartilaginous elements followed Fujita (1989). All bony components were digitized according to Bouck \& Thistle (1999).

\section{RESULTS AND DISCUSSION}

In line with the diural nomenclature of Arratia \& Schultze (1992), we assume that the last independent vertebral centrum is the second preural centra (PU2) and the urostyle is the bone structure resulting from the (ontogenetic or phylogenetic) fusion of the first preural centrum (PU1) and the first and second ural centra (U1 and U2). This terminal vertebra (sensu Paxton 1972) that articulates with the first hypurals, was formerly known as the 'ural vertebra' or urostyle (sensu Nybelin 1963), which in accordance to Dunn (1983) corresponds to vertebral centra fused along the evolutionary history and ontogeny of fish groups like the Myctophidae. Based on the polyural interpretation (e.g., Arratia \& Schultze 1992, Schultze \& Arratia 2013, Wiley et al. 2015), the urostyle could represent the compound autocentrum of preural centrum 1 plus and unknown number of ural centra (e.g., Doosey \& Wiley 2015), however, data of developmental biology studies in myctophid fishes are necessary to corroborate this statement in myctophids, a goal that it is out of the scope of this contribution.

The caudal skeleton of $T$. nigrescens have 6 hypurals bones (HY): 4 located posterodorsal and 2 in anteroventral position (Fig. 1). In contrast, T. mexicanus and T. oculeum display HY $1+2$ fused ventrally plus HY $3+4+5$ fused dorsally in a

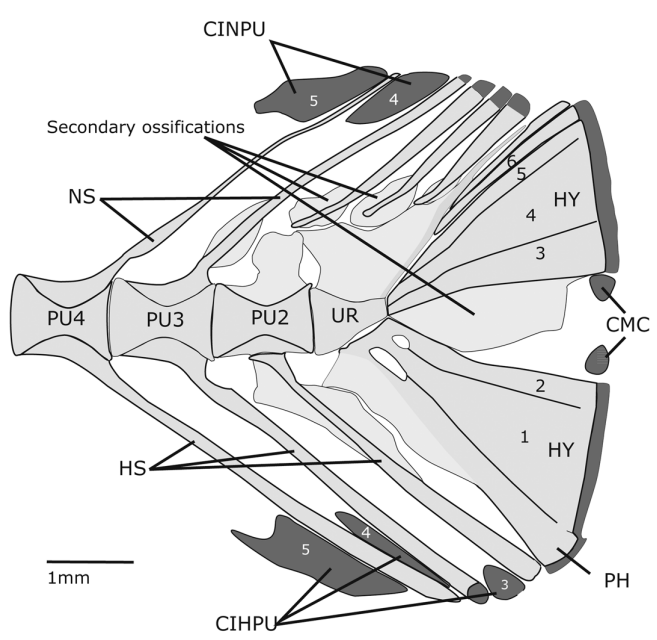

Figure 1. Lateral view of the caudal skeleton of Triphoturus nigrescens (Brauer, 1904) (CICIM AR-CI 2565). Hypurals (HY); median caudal cartilage (CMC); interhaemal spine cartilage (CIHPU); interneural spine cartilage (CINPU); neural spine (NS); haemal spine (HS); parhypural (PH); preural centrum (PU); urostyle (UR) / Vista lateral del esqueleto caudal de Triphoturus nigrescens (Brauer, 1904) (CICIMAR-CI 2565). Hipurales (HY); cartílagos medios caudales (CMC); cartílago interhemal de la espina (CIHPU); cartílago interneural de la espina (CINPU); espina neural (NS); espina hemal (HS); parahipural (PH); centro preural (PU); urostilo (UR) 


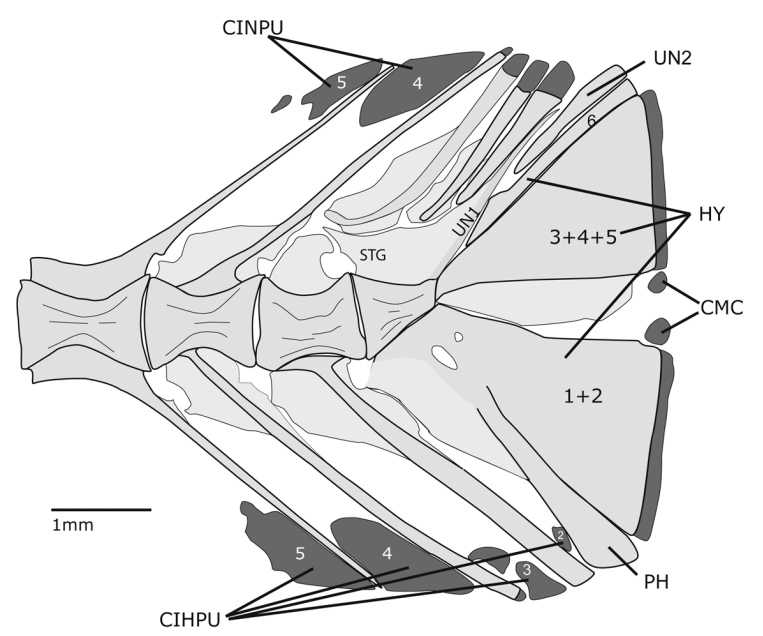

Figure 2. Lateral view of the caudal skeleton of Triphoturus mexicanus (Gilbert, 1890) (CICIM AR-Cl 2665). Hypurals (HY); median caudal cartilage (CMC); interhaemal spine cartilage (CIHPU); interneural spine cartilage (CINPU); parhypural (PH); stegural (STG); uroneural (UN) / Vista lateral del esqueleto caudal de Triphoturus mexicanus (Gilbert, 1890) (CICIMAR-CI 2665). Hipurales (HY); cartílagos medios caudales (CMC); cartílago interhemal de la espina (CIHPU); cartílago interneural de la espina (CINPU); parahipural (PH); uroneural (UN)

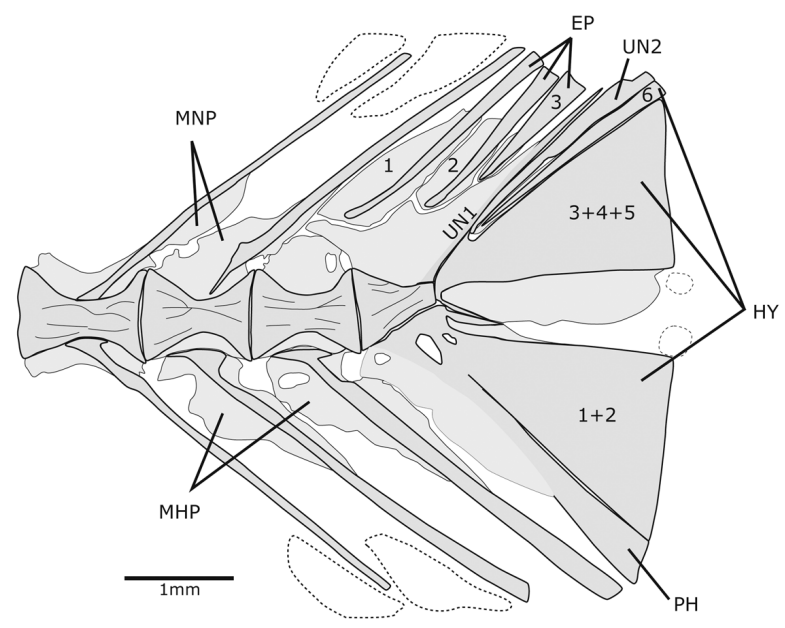

Figure 3. Lateral view of the caudal skeleton of Triphoturus oculeum (Garman, 1899)(SI052-372). Epurals (EP); hypurals (HY); median haemal plates (M HP); median neural plates (M NP); parhypural (PH); uroneural (UN) / Vista lateral del esqueleto caudal de Triphoturus oculeum (Garman, 1899) (SIO52-372). Epurales (EP); hipurals (HY); placas medias hemales (MHP); placas medias neurales (MNP); parahipural (PH); uroneural (UN) 
single plate separated from HY 6 (Figs. 2 and 3). Among these bony elements, there is a wide hypural diastema, wider in $T$. nigrescens than in its congeners.

On the other hand, the term 'hypural flange' used in Triphoturus and other myctophid genera for naming the bony extensions of ventral hypurals (e.g., Paxton 1972), was here considered as a modified haemal spine of the urostyle that represents the last haemal arch spanning from the ventral aorta, based on one specimen of T. mexicanus with neural and haemal elements stained. For this reason, the correct terminology for this structure should be parhypural (PH), as applied in other teleost groups (Nybelin 1963, Rojo 1991). Accordingly, the members of Triphoturus are characterized by 2 to 4 independent or fused posterodorsal hypural elements plus one to 2 independent or fused anteroventral hypural. This updates the information reported previously by Paxton (1972), who mentions a formula of 4 dorsal $+2-3$ ventral hypurals. The hypural fusion patterns and number of hypural observed in Triphoturus is a myctophiform condition similar to that established for other myctophid neoscolepids genera (Fujita 1990, Borden et al. 2013).

All species display two foramens: one located between the basis of the PH and HY 1; and other located between the bases of HY 1 and HY 2. A secondary ossification appears at the lower edge of HY $3+4+5$ in T. mexicanus and T. oculeum, which is in HY 3 in T. nigrescens. This structure exhibits high intraspecific morphological variation. At the base of the urostyle, the PH develops a laminar extension thickened anteriorly that reaches beyond the midpoint of the bony axis; T. oculeum differs from its congeners by the presence of a foramen in this structure (Fig. 3).

In Triphoturus, the caudal skeleton comprises 10 dorsal and 9 ventral principal caudal rays. Procurrent rays are spineshaped, its degree of flexibility regarding Paxton (1972) is 'great' as a result of the distal fusion between the two elements of each pair; T. mexicanus and T. oculeum have 6 or 7 dorsal and 6 or 7 ventral procurrent rays, while T. nigrescens shows 6 or 8 dorsal and 6 or 8 ventral rays.

Haemal spines (HS) of the second (PU2) and third preural centra (PU3) have at its base expanded haemal arches named median haemal plates (MHP) by Gosline (1960). In $T$. nigrescens, only the haemal spine of PU2 shows this MHP. In T. mexicanus and T. oculeum, PU2 and PU3 display MHPs; the main difference between the 2 species is the presence of a foramen in the proximal region of PU2 MHP in T. oculeum.
Moreover, the neural spines (NS) of PU3 are expanded at the base forming median neural plates (MNPs); T. mexicanus may or may not show an MNP in the PU3 neural spine. Likewise, T. oculeum shows an MNP in PU3, and occasionally also on the axis of the PU4 neural spine. In T. nigrescens, the MNP originates at the axis of the neural spine and not at its base, without exceeding the height of the anterior border of the first uroneural.

Two independent uroneurals (UN) are present in Triphoturus species. They are labeled as UN1 and UN2 because of their number and position, but not implying homology. The so-called UN1 has an anterior expansion, that is slender and tricuspid-shaped, termed stegural (Arratia \& Schultze 1992, Doosey \& Wiley 2015). The stegural shows slight interspecific variation in shape. The proximal tips of the epurals rest on the dorsal margin of the stegural. The anterior region of the stegural does not overlap the neural arch (spine lacking) of PU2; its base is attached to the urostyle. The paried UN2 is lanceolate-shaped.

Epurals (EP) present a secondary ossification at their proximal region (Fig. 1), which is more extended in EP2 of $T$. nigrescens, in contrast with the ossification of EP1 and EP3. In T. mexicanus and T. oculeum, EP1 displays a further development of these ossifications. EP3 is wedge-shaped in all Triphoturus species, and no secondary ossification is observed in most cases. Recent studies have shown the difficulty of standardizing the names of some skeletal structures as in the case of uroneurals and epurals in different groups of fishes and the importance of ontogenetic data to understand the origin and possible homologies involved (e.g., Doosey \& Wiley 2015).

Regarding the number of epurals in Triphoturus, Paxton (1972) mentioned the presence of 2 or 3 structures. All specimens analyzed here definitely show three epurals. Likewise, a comparative analysis of the morphology of epurals in other mictophids (e.g., the genus Diaphus) revealed that adult specimens show the fusion of these bones; however, a line of suture is apparent, indicating that epurals are not truly fused (Rubio-Rodriguez 2009).

Based on the criteria of Johnson (1984), we established the caudal formula for the bony elements of T. mexicanus and $T$. oculeum as:

\section{$6 / 3 / 2 / 4$}

I+II; III-V; VI 
In these 2 species, the caudal skeleton is composed of 6 hypurals, 3 epurals, 2 uroneurals and 4 haemal spines include a parhypural.

The caudal formula of $T$. nigrescens is: $6 / 3 / 2 / 4$

$$
\text { I+II; III; IV; V; VI }
$$

In addition, 2 free cartilages appear in the dorsal region supporting the dorsal procurrent rays. The first named interneural cartilage of the fourth preural centrum spine (CINPU4) is located between the neural spines of the third and fourth preural centra; the second cartilage of CINPU5 is located between the neural spines of the fourth and fifth preural centra.

Likewise, ventrally there are 3 or 4 free cartilages supporting the lower procurrent rays: the first is located between the lateral edge of the parhypural and the haemal spine of PU2, which corresponds to the interhaemal cartilage of the second preural centrum spine (CIHPU2); this structure was observed only in T. mexicanus. Between the haemal spines of PU2 and PU3 there is a second free or interhaemal cartilage of the third preural centrum spine (CIHPU3). A third CIHPU4 cartilage is located between the PU3 and PU4 haemal spines, and the last CIHPU5 is located between the PU4 and PU5 haemal spines.

All species have developed a pair of median caudal cartilages (CMC; see Fig. 2). In T. mexicanus and T. oculeum, these cartilages are relatively close to one another (separated by a distance equivalent to one-third at the urostyle [UR] height); this contrasts with T. nigrescens, where the separation between cartilages is equivalent to more than one-half of UR height, in addition to the presence of a wider hypural diastema.

In general, the comparison between the caudal skeleton of T. mexicanus and T. oculeum revealed a similar morphology; however, a distinctive trait of T. oculeum is the presence of foramens in the median haemal plate of the haemal spine of PU2, as well as in the parhypural bone. In contrast, several differences on the caudal composition and external morphology of T. nigrescens were detected; these findings in addition to the molecular differentiation established by Rodriguez-Graña et al. (2004), lead us to believe T. nigrescens should probably be the most divergent species within the group included in this study. However, a detailed assessment based on a phylogenetic approach should be conducted in further studies.

Material examined: Triphoturus mexicanus: CICIMAR-CI 2627 (4 ex.) [50-54 mm SL]; CICIMAR-CI 2645 (1) [69]; CICIMAR-CI 2647 (2) [84-93]; CICIMAR-CI 2665 (3) [6269]; CICIMAR-CI 2628 (3) [54-67]; CICIMAR-CI 2473 (5) [57-65].
T. oculeum : SIO 05-156 (2) [54-59]; SIO 52-367 (3) [64-68]; SIO 52-372 (4) [61-74]; SIO 52-404 (4) [56-66]; SIO 52-409 (3) [59-72].

T. nigrescens: CICIMAR-CI 2478 (8) [62-80]; CICIMAR-CI 2565 (3) [65-78]; CICIMAR-CI 2646 (2) [6874].

\section{ACKNOWLEDGMENTS}

We thank to Philip A. Hastings from SIO and José de la Cruz Agüero from CI-CICIMAR for their help and assistance during the examination of specimens. This study was partially supported by the Projects: SIP-IPN 20100652, 20110870 and 20141337. AFGA and HV thanks to Program EDI and COFAA-IPN; AFGA also thanks SNI-CONACYT. Finally, we thank to Maria Elena Sanchez-Salazar for proofreading this manuscript.

\section{LITERATURE CITED}

Arratia G \& H-P Schultze. 1992. Reevaluation of the caudal skeleton of certain Actinopterygian fishes: II. Salmonidae. Homologization of caudal skeletal structures. Journal of Morphology 214: 187-249.

Baldwin C \& G Johnson. 1999. Paxton concilians: A new genus and species of Pseudamine apogonid (Teleostei: Percoidei) from northwestern Australia: the sister group of the enigmatic Gymnapogon. Copeia 4: 1050-1071.

Bartolino V. 2005. Skeletal organization of caudal fin in Syngnathus abaster (Osteichthyes, Syngnathidae). International Journal of Morphology 23(4): 305-308.

Borden W C, T Grande \& WL Smith. 2013. Comparative osteology and myology of the caudal fin in the Paracanthopterygii (Teleostei : Acanthomorpha). In: Arratia G \& H-P Schultze \& MVH Wilson (eds). Mesozoic fishes 5 -Global diversity and evolution, pp. 419-455. Verlag Dr, Friedrich Pfeil, München.

Bouck L \& D Thistle. 1999. A computer-assisted method for producing illustrations for taxonomic descriptions. Vie et Milieu 49(2/3): 101-105.

Castro-Leal ME \& PM Brito. 2007. Intraespecific variation of the caudal fin skeleton in Osteoglossum bicirrhosum Cuvier 1829 (Teleostei; Osteoglossomorpha: Osteoglossidae). Zootaxa 1434: 1-26.

Doosey MH \& EO Wiley. 2015. Epural bones in teleost fishes: a problem of phylogenetic homology. Ichthyological Research 62: 131-144.

Doyle K 1998. Osteology of Dactyloscopus tridigitatus (Dactyloscopidae: Blennioidei). Bulletin Marine Science 63: 33-50.

Dunn JR. 1983. The utility of developmental osteology in taxonomic and systematic studies of teleost larvae: a review. NOAA Technical Report NMFS Circular 450: 1-19. 
Fraser T. 1968. Comparative osteology of the Atlantic snooks (Pisces, Centropomus). Copeia 3: 433-460.

Fujita K. 1989. Nomenclature of cartilaginous elements in the caudal skeleton of teleostean fishes. Japanese Journal of Ichthyology 36(1): 22-29.

Fujita K. 1990. The caudal skeleton of teleostean fishes, 897 pp. Tokay University Press, Tokyo.

Gosline W. 1960. Contributions toward a classification of modern isospondylous fishes. Bulletin of the British Museum (Natural History), Zoology 6: 327-365.

Gosline W. 1961. The perciform caudal skeleton. Copeia 3: 265-270.

Hulley P. 1986. A taxonomic review of the lanternfish genus Triphoturus Fraser-Brunner, 1949 (Myctophidae, Osteichthyes). Annals of the South African Museum 97(4): 71-95.

Johnson G. 1975. The procurrent spur: and undescribed perciform caudal character and its phylogenetic implications. Occasional Papers of the California Academy of Sciences 121: $1-23$.

Johnson G. 1984. Percoidei: development and relationships. In: Moser H, W Richards, D Cohen, M Fahay, A Kendall \& S Richardson (eds). Ontogeny and Systematics of Fishes. American Society of Ichthyologists and Herpetologists Special Publication 1: 464-498.

Keivany Y \& J Nelson. 1998. Comparative osteology of the greek ninespine stickleback, Pungitus hellenicus (Teleostei, Gasterosteidae). Journal of Ichthyology 38(6): 430-440.

Lauder G. 1989. Caudal fin locomotion in ray-finned fishes: historical and functional analysis. American Zoologist 29: 85102.

Lauder G. 2000. Function of the caudal fin during locomotion in fishes: kinematics, flow visualization, and evolutionary patterns. American Zoologist 40: 101-122.

McDowall R. 1999. Caudal skeleton in Galaxies and allied genera (Teleotei: Galaxiidae). Copeia 4: 932-939.

Moriyama Y \& H Takeda. 2013. Evolution and development of the homocercal caudal fin in teleosts. Development, Growth \& Differentiation 55: 687-698.

Moser H \& E Ahlstrom. 1996. Myctophidae: lanternfishes In: Moser H (ed). The early stages of fishes in the California Current region. California Cooperative Oceanic Fisheries Investigations Atlas 33: 387-475.

Nybelin O. 1963. Zur morphologie und terminologie des schwanzskelettes der Actinopterygier. Arkiv för Zoologi 15(35): 485-516.

Paxton J. 1972. Osteology and relationships of the lanternfishes (Family Myctophidae). Bulletin of the Natural History Museum of Los Angeles County 13: 1-81.
Potthoff T. 1984. Clearing and staining techniques. In: Moser H, W Richards, D Cohen, M Fahay, A Kendall \& S Richardson (eds). Ontogeny and systematics of fishes. American Society of Ichthyologists and Herpetologists Special Publication 1: 35-37.

Potthoff T \& J Tellock. 1993. Osteological development of the snook, Centropomus undecimalis (Teleostei, Centropomidae). Bulletin of Marine Science 52: 669-716.

Rodríguez-Graña L, G Herrera, L Herrera \& L Castro. 2004. Divergence of two forms of Triphoturus in the eastern Pacific based on mtDNA cytochrome $b$ gene sequences and larval morphology. Journal of Fish Biology 64: 1455-1461.

Rojo L. 1991. Dictionary of evolutionary fish osteology, 288 pp. CRC Press, Boca Raton.

Rubio-Rodriguez U. 2009. El complejo caudal de las especies del género Triphoturus Fraser-Brunner, 1949 (Teleostei: Myctophidae) en el Pacífico mexicano. Bachellor Thesis, Marine Biology Department, Universidad Autónoma de Baja California Sur, México, La Paz, 63 pp.

Shultze H \& G Arratia. 1989. The composition of the caudal skeleton of teleosts (Actinopterygii: Osteichthyes). Zoological Journal of the Linnean Society 97(3): 189-231.

Schultze H \& G Arratia. 2013. The caudal skeleton of basal teleosts, its conventions, and some of its major evolutionary novelties in a temporal dimension. In: Arratia G, H-P Schultze \& MVH Wilson (eds). Mesozoic fishes 5 -Global diversity and evolution, pp. 187-246. Verlag Dr. Friedrich Pfeil, München.

Stiassny M. 1996. Basal ctenosquamate relationships and the interrelationships of the myctophiform (scopelomorph) fishes. In: Stiassny M, L Parenti \& G Johnson (eds). Interrelationships of fishes, pp. 405-426. Academic Press, New York.

Taylor W. 1967. An enzyme method of clearing and staining small vertebrates. Proceedings of the United States National Museum 122: 1-17.

Tyler J. 1980. Osteology, phylogeny and higher classification of the fishes of the order Plectognathi (Tetraodontiformes). NOAA Technical Report NMFS Circular 434: 1-422.

Wiley E, A Fuiten, M Doosey, B Lohman, C Merkes \& M Azuma. 2015. The caudal skeleton of the zebrafish, Danio rerio, from a phylogenetic perspective: A polyural interpretation of homologous structures. Copeia 103(4): 740750.

Wisner R. 1974. The taxonomy and distribution of lanternfishes (family Myctophidae) on the eastern Pacific Ocean. US Navy Ocean Resources. Development Activity NORDA Report 3: $1-229$. 